\title{
EFFICACY OF ALBENDAZOLE AGAINST Moniezia spp. IN SHEEP AND CATTLE
}

\section{K. CHROUST}

\begin{abstract}
Department of Parasitology. Faculty of Veterinary Medicine. University of Veterinary and Pharmaceutical Sciences. Brno
\end{abstract}

Received June 22, 1998

Accepted August 19, 1998

\begin{abstract}
Chroust K.: Efficacy of Albenda-ole against Moniezia spp. in Sheep and Cattle. Acta vet. Brno, 1998, 67: 175-181.

The paper presents results of the anthelmintic efficacy verification of albendazole in sheep and cattle naturally infected by tapeworms Moniezia expansa and $M$. benedeni. We tested the dose of $5 \mathrm{mg}$ per $1 \mathrm{~kg}$ of body weight applied as a $2.5 \%$ suspension in sheep. One hundred percent efficacy of this dose was proved both in a controlled test on 12 lambs and in field studies on two flocks of ewes and lambs (amounting to 380 and 420 individuals) in which we invariably evaluated groups of 30 treated and 30 untreated control individuals using quantitative ovoscopic methods. We also studied the dynamics of the monieziosis prevalence in a flock of 70 sheep of all age categories and performed deworming using albendazole during peak infections in 1995 to 1997. Even in cases when there was a quick and repeated rise of the infection during the pasture period, the application of albendazole decreased ovoscopic findings to zero values and to considerably low prevalence in the second and third year of our study. The occurrence of monieziosis in cattle was nearly sporadic and the application of albendazole in the dose of $7.5 \mathrm{mg}$ per $1 \mathrm{~kg}$ of body weight was $100 \%$ effective when given to individual animals as a suspension. Mass application using medicated feeds did not ensure appropriate intake of therapeutic doses in all animals treated. Monieziosis is an important health problem particularly of sheep in the Czech Republic and albendazole may be considered as a drug of choice.
\end{abstract}

Monie:ia expansa, M. benedeni, sheep, cattle, albenda:ole, efficacy

Long-term studies of helminthoses in cattle and sheep in the Czech Republic proved that tapeworms belonging to the genus Monie-ia may be an important pathogenic agent causing mass diseases and mortality, particularly in lambs. The change in the technology of sheep rearing that uses pasture rearing and moves the lambing season to spring months, at present employed by most of our breeders, makes it possible for the animals, contrary to the previously used system of winter lambing, to be permanently on pastures and minimizes the cost of sheep breeding and lamb's meat production. This technology of sheep breeding, however, puts heavy demands on effective parasite control due to the fact that the lambs are subjected to permanent reinfections on pastures from their first days of life.

The monography on the genus Moniezia by Baer (1927) includes 6 main species, i.e. $M$. benedeni, M. expansa, M. denticulata, $M$. pallida, $M$. rugosa and $M$. trigonophora. Many studies concerned the morphology and biology of these tapeworms. In all, 73 and 43 species of oribatid mites were found to be intermediate hosts in $M$. expansa and $M$. benedeni, respectively (Denegri et al. 1993). There are two species that are important under our

\footnotetext{
Address for Correspondence:

Prof. MVDr. Karel Chroust. DrSc

Department of Parasitology

Faculty of Veterinary Medicine

Lniversity of Veterinary and Pharmaceutical Sciences

Palackého 1. 612 42 Brno. Czech Republic
}

Phone: $++20-5-41562262-3$

Fax: $+420-5-41562266$

E-mail: modry@dior.ics.muni.cz 
conditions, i.e. M. expansa occurring mainly in sheep and M. benedeni in cattle. sheep and wild ungulates.

The therapy of monieziosis has undergone a complex development. The first reports described the use of a $1 \%$ solution of copper sulphate in doses ranged according to the age of sheep ( $\operatorname{Lax} 1956$ ). Chroust (1973) found high, practically $100 \%$ efficacy of resorantel (Terenol Hoechst AG) in the dose of $65 \mathrm{mg}$ per $1 \mathrm{~kg}$ of body weight in lambs naturally infected by M. expansa and M. benedeni. Daněk et al. (1977) verified the piperazine salt of niclosamide produced by Bayer and called Taenifugin gran. in sheep and young cattle. It was applied as a medicated feed in the dose of $90 \mathrm{mg}$ per $1 \mathrm{~kg}$ of body weight and 100\% efficacy both during controlled tests and field studies with regards to the extensity and intensity was achieved. The niclosamide was also used with $100 \%$ efficacy in controlling the mass occurrence of monieziosis leading to high mortality in roe deer in the area of South Moravia (Forejtek and Chroust 1990). It was applied as medicated feeds in the dose of $100 \mathrm{mg}$ per $1 \mathrm{~kg}$ of body weight. as well. The efficacy of imidazole compounds, particularly in treating monieziosis in sheep, goats and cattle, has been studied recently. Bauer (1990) compared albendazole, oxfendazole, febantel and praziquantel in naturally infected sheep and found $100 \%$ efficacy using albendazole in the dose of $3.8 \mathrm{mg}$ per $1 \mathrm{~kg}$ of body weight and febantel in the dose of $5 \mathrm{mg}$ per $1 \mathrm{~kg}$ of body weight. Milla et al. (1992) proved 100\% efficacy of 7-8.8 mg per $1 \mathrm{~kg}$ of body weight of albendazole against M. expansa in sheep and goats in Romania. Gill et al. (1990) obtained $92.12 \%$ efficacy using albendazole against $M$. expansa in sheep in India. The efficacy of albedazole against $M$. benedeni and M. expansa reaching 88.8 to $97.6 \%$ in cattle was studied by Anwar et al. (1996) in Pakistan. Other imidazoles have been studied. as well. A mbrosi and Grelloni (1991) proved mebendazole in the dose of $20 \mathrm{mg}$ per $1 \mathrm{~kg}$ of body weight to be highly effective against $M$. expansa in sheep in Italy. Fenbendazole in the dose of $10 \mathrm{mg}$ per $1 \mathrm{~kg}$ of body weight was 100\% effective in sheep naturally infected by M. expansa in studies by Babíček et al. (1990) and, likewise, Čorba et al. (1979) proved the same efficacy after the application of $15 \mathrm{mg}$ of fenbendazole per $1 \mathrm{~kg}$ of body weight and after the combined application of $5 \mathrm{mg}$ of fenbendazole together with $7.5 \mathrm{mg}$ of triclambendazole per $1 \mathrm{~kg}$ of body weight (Č orba et al. 1988).

\section{Materials and Methods}

The albendazole efficacy verification was performed using a controlled test in lambs and field studies on sheep and cattle of all age categories naturally infected by tapeworms $M$. expansa and $M$. benedeni.

Methods employed in the controlled test

Albendazole in the dose of $5 \mathrm{mg}$ per $1 \mathrm{~kg}$ of body weight was applied as a suspension (Vermitan $2.5 \%$ susp. Sanofi) per os to 6 Merino lambs that were 5-6 months old. Other 6 lambs of the same age were used as controls. Ovoscopic examinations and quantitative determinations of numbers of eggs shed (EPG) were performed on days 7 and 0 before the application and days 3,7 or 10 after the application. The control animals were examined on the same days. The treated and untreated control animals were slaughtered 9 to 11 days after the treatment and then we performed helminthological autopsy in order to count the number of scolices and the amount of tapeworm segments ( $\mathrm{ml})$.

Methods employed in field studies on sheep and cattle

During field studies we tested the dose of $5 \mathrm{mg}$ of albendazole per $1 \mathrm{~kg}$ of body weight (Vermitan $2.5 \%$ susp. Sanofi. Aldifal 2.5\% susp. Mevak) in two flocks of Merino and crossbred ewes. yearlings and lambs amounting to 380 and 420 individuals. There were left 30 control untreated individuals in each flock. The ovoscopic examination and EPG determination was performed in both flocks on 30 animals of the treated and control groups on the day of the treatment and then 7 and 14 days after the treatment.

Another study was aimed at the dynamics of the prevalence of Monie-ia spp. egg shedding in a flock of 70 ewes. yearlings and lambs during the years 1995 to 1997. Fecal samples were taken at regular monthly intervals 
during the whole pasture season. Albendazole in the dose of $5 \mathrm{mg}$ per $1 \mathrm{~kg}$ of body weight was used to treat ewes and yearlings before driving them out to pasture (April). lambs. ewes and yearlings during the period of maximum intensity of infection (end of June) and in the end of the pasture season (end of October). The fecal samples were examined by the flotation method and the percentage of positive animals (prevalence) was determined.

As far as cattle are concerned. the field studies were performed on two herds of cattle with mass (90 animals) and sporadic (30 animals) occurrence of tapeworms Moniezia spp during pasture. We used albendazole in the dose of $7.5 \mathrm{mg}$ per $1 \mathrm{~kg}$ of body weight applied as granulated medicated feeds (Vermitan $20 \%$ gran. Sanofi) to treat animals from the herd with mass occurrence of monieziosis and applied as a suspension (Aldifal 10\% susp. Mevak) to animals with sporadic monieziosis. The efficacy of this treatment was checked using regular fecal sampling 7.14 and 20 days after the treatment. In all, we treated 21 calves, heifers and cows.

\section{Results}

Results of the controlled test

The results of quantitative ovoscopic examinations (EPG) and helminthological autopsies of 6 treated and 6 control lambs before and after the albendazole therapy are given in Tab. 1.

Table 1

Ovoscopic and autopsy findings in lambs from the conntrolled test

\begin{tabular}{|c|c|c|c|c|c|c|c|c|c|c|}
\hline \multirow[t]{2}{*}{ Group } & \multirow[t]{2}{*}{$\begin{array}{l}\text { No. of } \\
\text { lambs }\end{array}$} & \multirow[t]{2}{*}{$\begin{array}{l}\text { Albendazole } \\
\text { dose } \\
\left(\mathrm{mg} \cdot \mathrm{kg}^{-1}\right)\end{array}$} & \multicolumn{2}{|c|}{$\begin{array}{l}\text { Average EPG } \\
\text { before treatment } \\
\text { (day) }\end{array}$} & \multicolumn{3}{|c|}{$\begin{array}{l}\text { Average EPG } \\
\text { after treatment } \\
\text { (day) }\end{array}$} & \multicolumn{2}{|c|}{ Results of the section } & \multirow[t]{2}{*}{$\begin{array}{c}\text { Efficacy } \\
(\%)\end{array}$} \\
\hline & & & 7. & 0. & 3. & 7. & 10. & $\begin{array}{l}\text { Volume of } \\
\text { proglotids } \\
(\mathrm{ml})\end{array}$ & $\begin{array}{l}\text { Number of } \\
\text { tapeworm } \\
\text { scolices }\end{array}$ & \\
\hline Treated & 6 & 5 & 2300 & 3150 & 210 & 0 & 0 & 0 & 0 & 100 \\
\hline Control & 6 & 0 & 3400 & 3350 & 2400 & 1850 & 3100 & $\begin{array}{c}12.20 \\
42,26 \\
6.17\end{array}$ & $\begin{array}{l}2.3 . \\
7.6 \\
2.3\end{array}$ & - \\
\hline
\end{tabular}

High quantitative EPG values found before the treatment remained on this level in control lambs, whereas in the treated lambs they decreased considerably 3 days after the albendazole treatment and were negative from the 7 th day of examination onwards. Likewise, the autopsy findings in treated lambs were completely negative. There were found 2-7 (in all, 23) scolices and tapeworm segments amounting the volume of 6 to $62 \mathrm{ml}$ (in all, $123 \mathrm{ml}$ ) in individual lambs of the control group. Albendazole in the dose of $5 \mathrm{mg}$ per $1 \mathrm{~kg}$ of body weight was $100 \%$ efective in the controlled test.

\section{Results of field studies on sheep and cattle}

Tab. 2 summarizes the results of the albendazole efficacy verification based on the reduction of the number of eggs shed before and after the treatment in two flocks of ewes, yearlings and lambs consisting of 30 animals in the treated and control groups.

Using ovoscopic quantitative examination methods in field studies on two flocks consisting of 380 and 420 ewes, yearlings and lambs we obtained negative findings in all the 
Table 2

Quantitative (EPG) Moniezia spp. eggs findings

in sheep in filed studies before and after

the treatment by albendazole

\begin{tabular}{|l|c|c|c|c|c|c|}
\hline Group & \multirow{2}{*}{$\begin{array}{c}\text { No. of } \\
\text { sheep }\end{array}$} & $\begin{array}{c}\text { Average EPG } \\
\text { before treatment } \\
\text { (day) }\end{array}$ & \multicolumn{2}{|c|}{$\begin{array}{c}\text { Average EPG } \\
\text { after treatment } \\
\text { (day) }\end{array}$} & $\begin{array}{c}\text { Albendazole } \\
\text { dose } \\
\left(\mathrm{mg} \cdot \mathrm{kg}^{-1}\right)\end{array}$ & $\begin{array}{c}\text { Effectiveness } \\
(\%)\end{array}$ \\
\cline { 2 - 6 } & & 0. & 7. & 14. & & 100 \\
\hline Treated & 30 & 660 & 0 & 0 & 5 & - \\
\hline Control & 30 & 740 & 550 & 690 & - & 100 \\
\hline Treated & 30 & 160 & 0 & 0 & 5 & - \\
\hline Control & 30 & 145 & 130 & 180 & - & 100 \\
\hline
\end{tabular}

animals treated. Contrary to this, animals from the control untreated group continued to shed the eggs during the whole period of study. The treatments in field studies were $100 \%$ efficient, as well.

The application of albendazole to the flock of ewes, yearlings and lambs proved to be of high therapeutic value during the three-year study (Fig. 1 and 2). The dynamics of the Moniezia spp. infection had a typical course and both in lambs, ewes and yearlings the prevalence was rising quickly during the first months of pasture. De-worming in lambs by the end of June resulted in the decrease of the egg shedding to almost zero values. Then. there was a repeated but rather moderate increase in the prevalence during the summer months (August to September) which was completely controlled by the application of albendazole at the end of the pasture season (end of October). As far as ewes and lambs are concerned, the curve showing the dynamics of egg shedding was similar to lambs, but the prevalence reached considerably lower values. The ewes and yearlings were dewormed before pasture (April), in the period of the first maximum (end of June. or the first decade of July in 1997) and in the end of the pasture season (end of October). As it is seen from the graphs, the prevalence decreased considerably both in lambs. ewes and yearlings during the three-year albendazole application (i.e. in lambs from the $60 \%$ maximum in 1995 to $20 \%$ and in ewes and yearlings from $25 \%$ to $10 \%$ ). Autumn deworming resulted in minimal rates of Moniezia occurrence during winter housing of sheep, as well.

\section{Discussion}

High efficacy of albendazole in the doses of $5 \mathrm{mg}$ per $1 \mathrm{~kg}$ of body weight in sheep and $7.5 \mathrm{mg}$ per $1 \mathrm{~kg}$ of body weight in cattle against tapeworms Moniezia spp. was verified both in lambs in a controlled test and in sheep and cattle of all age categories in field studies. Our results agree with and correlate to findings by other authors proving albendazole in sheep (Bauer 1990; Milla et al. 1992 and Gill et al. 1990) and cattle (Anwar et al. 1996). Another positive factor of this anthelmintic, mentioned by the aboveauthors and Chroust et al. (1997), is its efficacy against other gastrointestinal nematodes. Highly significant results were obtained after the long-term use of albendazole aimed at controlling the peaks of tapeworm infections during the pasture 


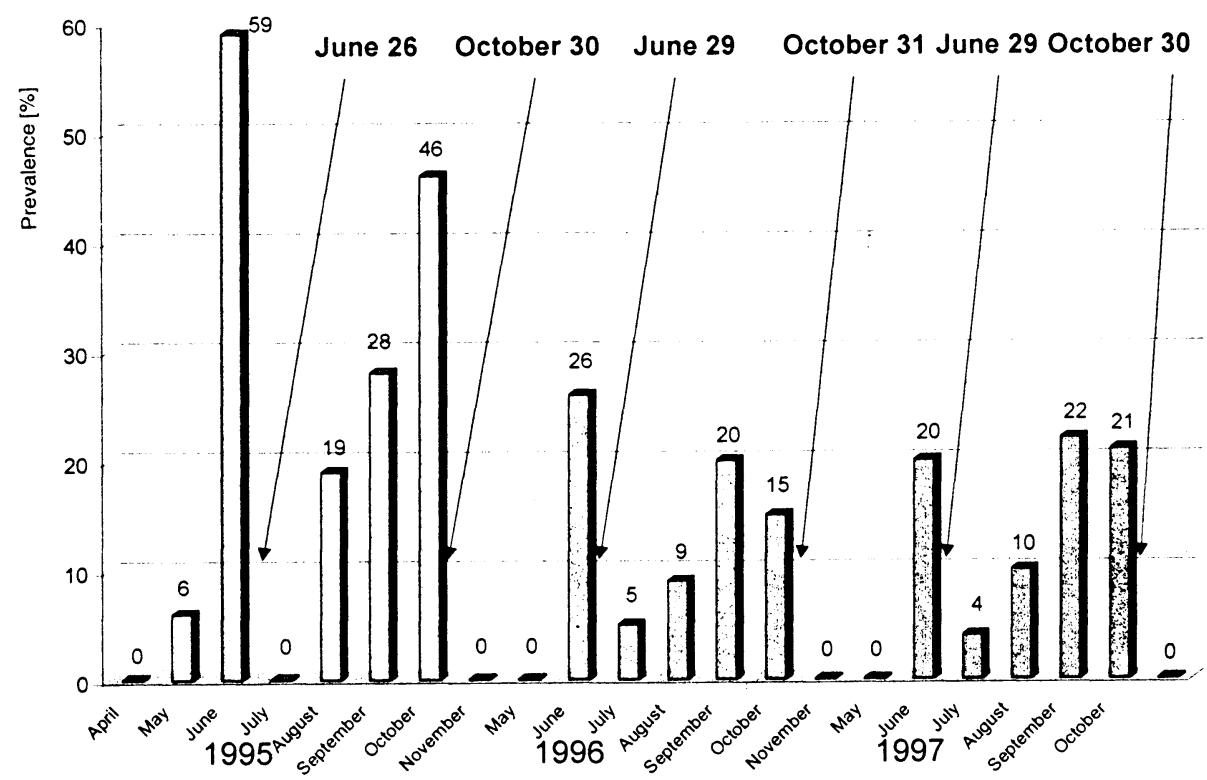

Fig. I. The dynamics of the Monie-ia spp. prevalence in lambs treated by albendazole during the pasture seasons 1995 to 1997 (vertical rows indicate dates of deworming)

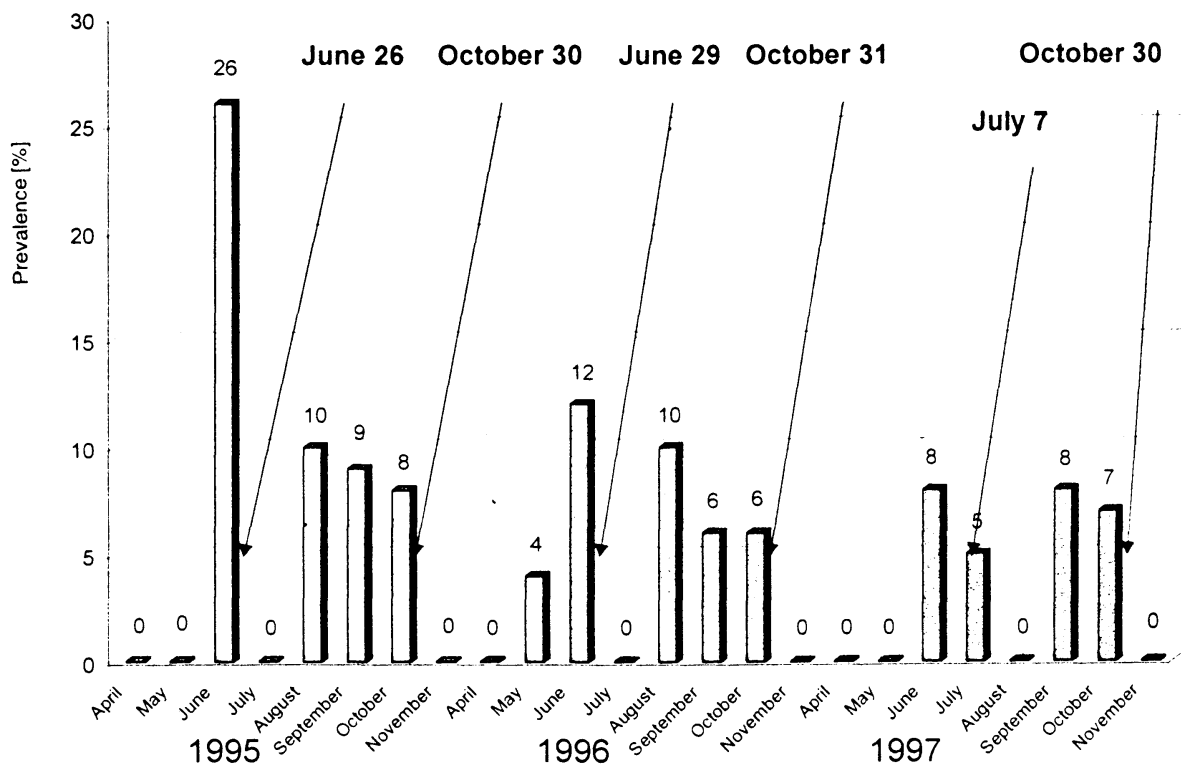

Fig. 2. The dynamics of the Moniezia spp. prevalence in ewes and yearlings treated by albendazole during the pasture seasons 1995 to 1997 (vertical rows indicate dates of deworming) 
season. On the basis of these results we can say that optimal terms for deworming are April just before driving ewes and yearlings out to pasture, the end of June or at the latest the beginning of July (ewes, yearlings and lambs), and the end of the pasture season in autumn. Deworming the flock of sheep in 1995 to 1997 in the above - described way ensured the decrese in the prevalence in all age categories to almost zero values right after the albendazole application and resulted in the considerable decrease of the prevalence during the second and third year of study. Autumn deworming maintains minimal rates of infections during winter housing.

The occurrence of monieziosis is low in cattle in the Czech Republic. Even the sporadic findings require to be properly treated by anthelmintics that are most easily applied as medicated feeds on pastures. This method of application, however, does not ensure the intake of full therapeutic doses by all animals treated. In order to reach $100 \%$ efficacy in cattle as in our studies, it is necessary to recommend the albendazole suspension application to individual animals.

The high tolerance of albendazole is another positive factor. There was no case of negative side effects both in sheep and cattle and albendazole applied in mass therapeutic procedures in cattle as medicated feeds was taken by the animals without any problems.

\section{Účinnost albendazolu proti Moniezia spp. u ovcí a skotu}

V práci jsou prezentovány výsledky ověřování anthelmintické účinnosti albendazolu u ovcí a skotu prrirozeně invadovaných tasemnicemi Moniezia expansa a $M$. benedeni. U ovcí byla testována dávka $5 \mathrm{mg} \cdot \mathrm{kg}^{-1}$ ž.h. ve formě $2.5 \%$ suspenze. $100 \%$ účinnost této dávky byla prokázána jednak $v$ kontrolovaném testu na 12 jehňatech a jednak $v$ terénních pokusech ve dvou stádech bahnic, jehnic a jehňat ( 380 a 420 ks), v nichž bylo kvantitativní ovoskopií sledováno 30 léčených a 30 kontrolních zvírat. V letech 1995-1997 byla dále sledována dynamika prevalence monieziózy ve stádě 70 ovcí všech věkových skupin a prováděna dehelmintizace albendazolem $v$ období vrcholu infekce. I při rychlém a opakovaném nárůstu infekce během pastevního období, sní̌ila aplikace albendazolu ovoskopické nálezy na nulové hodnoty a ve druhém a třetím roce sledování byl zaznamenán výrazný pokles prevalence. U skotu byl výskyt monieziózy vesměs sporadický a léčba albendazolem $v$ dávce $7,5 \mathrm{mg} \cdot \mathrm{kg}^{-1}$ ž.h. měla $100 \%$ účinnost při individuální aplikaci suspenze. Hromadná aplikace v medikovaném krmivu nezajištovala spolehlivý príjem terapeutické dávky u všech léčených kusů. Moniezióza představuje v podmínkách ČR významný zdravotní problém především u ovcí a albendazol je možno považovat za lék volby.

\section{Acknowledgements}

This work was supported by the Grant Agency of the Ministry of Agriculture of the Czech Republic. Grant No. EP 7281 .

\section{References}

AMBROSI. M.. GRELLONI. V. 1991: Prove di campo sull'uso del mebendazolo nel poliparassitismo ovino. Obiettivi e Documenti Veterinari 12: 89-91

ANWAR. A. H.. HAYAT. C. S.. AMIR. M. I. 1996: Prevalence of gastrointestinal helminthiasis and comparative efficacy of anthelmintics in parasitised buffalo calves. Pakistan Veter. J. 16: 160-163

BABÍCEK. K.. DANĚK. J.. ROUTA. V.. BENUŠKA. N.. KINKOROVÁ. J. 1990: Ověření účinnosti 
fenbendazolu v novém prípravku Fenrymin susp. (GALENA) u ovcí, skotu a koní. Biologizace a chemizace živočišné výroby. Veterinaria $25:$ 475-483

BAER, J. 1927: Monografie des cestodes de la familia Anoplocephalidae. Suppl. Bull. Oc. Biol. France et Belgique 10: $1-2+1$

BAUER. C. 1990: Comparative efficacy of praziquantel, albendazole, fabantel and oxfendazole against Moniezia expansa. Vet. Rec. 127: 353-354

CHROUST. K. 1973: Efficacy of the anthelmintic Terenol (resorantel) against the fluke Paramhistomum (Liorchis) scotiae in cattle and against the tapeworm Moniezia spp. in lambs. Acta vet. Brno 42: 281-286

CHROUST. K.. HORÁK. F., ŽlŽLAVSKÁ. S. 1997: Dynamika gastrointestinálních helmintóz při permanentní pastvě skotu a ovcí. Veterinářstvi 47: 60-62

CORBA. J.. LIETAVA. P.. DUWEL, D., REISENLEITER. R. 1979: Efficacy of fenbendazole against the most important trematodes and cestodes of ruminants. Br. vet. J. 135: 318-323

ČORBA, J.. HOVORKA. J., ŚPALDONOVÁ. R. 1988: Efficacy of a combined fenbendazole/triclambendazole preparation against helminths in sheep and cattle. Helminthologia 25: 157-163

DANÉK, J., KINKOROVÁ. J.SSEVČÍKOVÁ, E., ČORBA, J., PAČENOVSKÝ, J., POPOVIČ, Ś., KRUPICER, J. 1977: Taenifugin granulát a tablety, veterinární př́pravky s obsahem piperazinové soli niklosamidu. Veterinaria SPOFA 19: 3-4, 17-59

DENEGRI, G.. BERnADINA. W., SERRANO, J. P., CAABEIRO, F. R. 1998: Anoplocephalid cestodes of veterinary and medical significance: a review. Folia Parasitol. 45: 1-8

FOREJTEK. P., CHROUST, K. 1990: Moniezióza jako př́čina úhynů srnči zvěře a možnosti její léčby. Veterináŕství 40: 116-117

GILL. J. S.. BALI. H. S., MIGLANI. A. 1990: Comparative efficacy of anthelmintics against monieziasis in sheep. Indian J. Parasitol. 14: 137-139

LAX. T.: 1956: Nemoci ovcí. Státní zemědělské nakladatelství, Praha, pp. 121-125

MILLA. C.. ISAR. O., MITREA. L. I. 1992: Testarea rombendazolului in helmintoze ale aparatului digestiv si respirator la ovine si caprine. Lucrari Stintifice. Univ. De Stiinte Agron., Bucuresti, Seria C, Med. Veter. 35: 99-102 